Sohini Pyne

\title{
Engagement of Contemporary Communities with the Shared Heritage Resources of the Dwindling Minorities of Central Calcutta
}

Compromiso de las comunidades actuales con los recursos patrimoniales compartidos de las minorías decrecientes del Centro de Calcuta

Envolvimento das comunidades contemporâneas com os recursos do património partilhado das minorias em declinio de Calcutá Central

Keywords | Palabras clave | Palavras chave

Urban heritage, Cultural pluralism, Shared built heritage, Community engagement, Participatory methods

Patrimonio urbano, Pluralismo cultural, Patrimonio construido compartido, Compromiso comunitario, Métodos participativos

Património urbano, Pluralismo cultural, Património construído partilhado, Envolvimento da comunidade, Métodos participativos

\begin{abstract}
Resumen | Resumo
The accelerated growth of Calcutta as a trading center under the British between the mid-18th and early 20th centuries brought an influx of diverse trading communities, including Armenians, Baghdadi Jews, Parsis, and Chinese, who settled in the historic bazaar nucleus of the city known today as Central Calcutta. These ethnoreligious communities erected significant heritage buildings reflecting their cultures. But with large-scale emigration and a rapidly dwindling local population, this shared built heritage is in neglect and has little or no relevance for Central Calcutta's contemporary communities. This paper discusses the issues faced by these heritage resources and offers recommendations for enhancing community engagement, initiating co-management and developing common goals amongst contemporary communities so as to effectively safeguard this built heritage of dwindling minorities.
\end{abstract}

El crecimiento acelerado de Calcuta como centro del comercio bajo el dominio británico entre mediados del siglo XVIII y principios del XX fue testigo de la llegada de diversas comunidades de comerciantes, como armenios, judíos de Bagdad, parsis y chinos, que se asentaron en la zona del Bazar histórico de la ciudad, lo que hoy se denomina Calcuta central. Estas comunidades establecieron recursos patrimoniales importantes que conmemoraban la vida sociocultural de la ciudad. Sin embargo, con la migración masiva y el rápido despoblamiento de la zona, el patrimonio edificado común de estas comunidades etno-religiosas ha quedado abandonado. Este patrimonio apenas tiene relevancia o carece completamente de ella para las actuales comunidades de Calcuta central. Este artículo trata de los problemas que aquejan a estos recursos patrimoniales y ofrece recomendaciones para mejorar el compromiso comunitario, iniciar 
la gestión conjunta y desarrollar objetivos compartidos por las comunidades actuales para salvaguardar eficazmente el patrimonio construido de las minorías hoy en retroceso.

O crescimento acelerado de Calcutá como centro comercial sob o domínio britânico entre meados do século XVIII e o início do século XX viu o influxo de diversas comunidades mercantis, incluindo os Arménios, Judeus Bagdadi, Parses e Chineses, que se estabeleceram no núcleo histórico do Bazar da cidade, conhecido hoje como Calcutá Central. Estas comunidades estabeleceram recursos patrimoniais significativos em comemoração da sua vida sociocultural na cidade. No entanto, com a emigração em grande escala e uma população local em rápido declínio, o património construído comum destas comunidades etno-religiosas foi negligenciado. Este património tem pouca ou nenhuma relevância para as comunidades contemporâneas de Calcutá Central. Este artigo discute as dificuldades enfrentadas por estes recursos patrimoniais e fornece recomendações para reforçar o envolvimento da comunidade, iniciar a co-gestão e desenvolver objectivos comuns entre as comunidades contemporâneas, para salvaguardar eficazmente os recursos patrimoniais construídos que são partilhados pelas minorias em declínio nos dias de hoje.

\section{Introduction}

Calcutta has seen an influx of immigrants from various parts of the world from its earliest days - mainly Armenians, Baghdadi Jews, Parsis, and Chinese, who made their way to Calcutta for commercial reasons together with European traders. Some new communities, such as the AngloIndians, were also formed from this synthesis. Thanks to the flourishing trade established by the British East India Company, Calcutta, which in 1690 was just a group of hamlets, rapidly turned into a truly cosmopolitan city with diverse ethnoreligious communities that each contributed a piece of their own identity to its built heritage. Being chiefly engaged in trade, these communities settled in the historic bazaars, and this area, along with parts of Burrabazar, Tiretta Bazaar and Bowbazar, also known as Central Calcutta, soon developed a culturally plural character. Some of these communities made Calcutta their home, and some returned to their places of origin after three or four generations. All, however, left a stock of architectural resources reflecting their life in the city. These structures are architecturally diverse in terms of their functional and spatial typology, scale and proportion, construction techniques, building materials, and ornamentation, with both local and colonial influences lending a unique character to the urban fabric.

But the scenario is different today. With the large-scale emigration of Calcutta's Armenian, Jewish, Parsi, Chinese and Anglo-Indian communities, their population has dwindled. As they were located in the historically dense core of the city, the gap left has been filled by "communities of today", described below, that are either unaware of these heritage resources or attach little or no value to them. The preservation of the shared built heritage of dwindling minority communities has low priority in these dense commercial neighborhoods, due to which the structures are threatened with encroachment, abandonment, and dereliction. This paper asks the question: what happens to the built heritage of communities that have moved on? Who will now take ownership to ensure the conservation of these resources - especially living heritage, the less famous but equally significant structures, not under official protection? How do these seemingly distant factors affect heritage conservation today? (ICOMOS 2005: 5). This paper also aims to show that these resources are not only of sociocultural and historical significance for bygone communities but are also significant today by virtue of their artistic and architectural qualities, exhibiting universal values that also serve the communities of today, irrespective of ethnoreligious background.

Figure 1: "Of the Nations Most Known in Hindoostan" (Solvyns 1811)

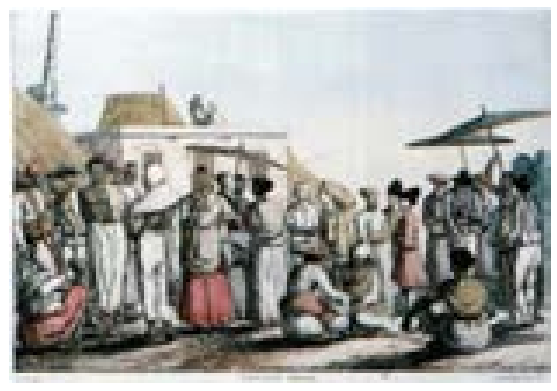




\section{Methodology}

To apprehend the historical evolution of dwindling minority communities in Calcutta, a review of the existing literature was undertaken. This identified the neighborhoods where these trading communities lived, along with their architectural heritage. To examine local community engagement, activities at heritage sites and their surrounding areas were studied and two distinct communities were identified: ethnoreligious and occupational. Informal discussions gauged these communities' perceptions of heritage. In-depth interviews were conducted with representative members of ethnoreligious communities and semi-structured interviews with occupational ones, including wholesale electrical traders around the Rustomjee Cawasji Banaji Agiary, shopkeepers and informal vendors along Brabourne Road, by the Armenian Church, the Neveh Shalom Synagogue and the Magen David Synagogue, and office-goers in Old Chinatown. The key findings were then analyzed and summarized .

\section{Migration of trading communities to Central Calcutta and their architectural heritage}

The migration of diverse ethnoreligious communities to Calcutta had a direct impact on the city's morphology, and distinct neighborhoods soon took shape. Native comprador (colonial agent) families were concentrated in the north of the city, while European traders and company officials gravitated toward Fort William in the south. Between them an "Intermediate Town" emerged, a cosmopolitan district with residential and commercial establishments of diverse trading communities, along with their houses of worship. The Intermediate Town was at the heart of the city, in Central Calcutta, with the popular Burrabazar, Tiretta Bazaar and Bowbazar districts. Though these communities migrated to the bazaar areas chiefly for trade, each one was quick to build houses of worship and gathering places close to their residential and trading quarters. The architecture that developed as a result was a fusion of these communities' traditional styles, popular European Colonial styles and local Bengali materials and techniques. The historical backgrounds of these migrant communities are outlined below along with their contributions to architectural heritage, enhancing the city's diversity with their spatial arrangements, their scale and proportions, and their ornamentation and iconography.

Figure 2: Possible neighborhoods of the migrant communities along with the identified heritage structures

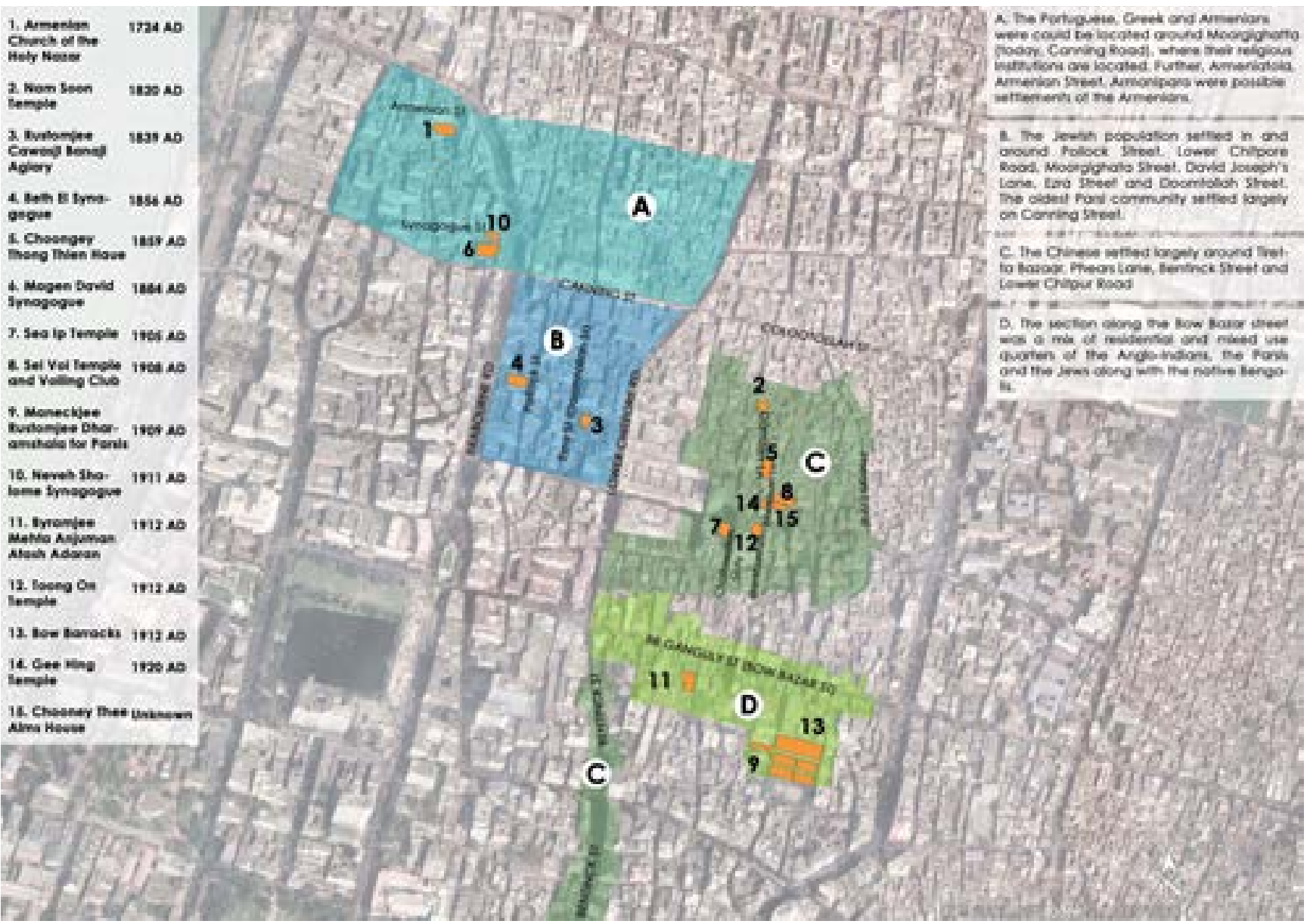




\section{Armenians}

The Armenians, "pioneers of foreign trade in India”, formed trade relationships with Bengal prior to the advent of the European trading powers. The community migrated from Shiraz and New Julfa in Persia (Bhattacharya 2009: 71 ), and traded in Sutanati, a cotton-bale market in north Calcutta (Seth 1897: 40). The Armenian genocide in Turkey brought a second influx of Armenians to Calcutta in the early 1900s and the community settled largely in the Burrabazar area, around the Armenian Holy Church of Nazareth (Bhattacharya 2009: 76).

This church was built in 1724 by Mr. Gavond, a Persian architect, and is one of the city's oldest churches (Seth 1937: 429-430), with notable Middle Eastern influences. It is rectangular in plan, with a wide, two-story nave flanked by two aisles. The columns dividing the nave and aisles are Doric in form but with stout proportions, supporting pointed cinquefoil arches of unique geometry. A staircase leads to a gallery above the aisles and the interior is richly decorated with frescoes and paintings. At the altar are twelve candles symbolizing the twelve apostles. The façade of the longer side is divided into seven bays, each with a rose window at its center letting in abundant light. On the shorter façade, a belfry with prominent corner moldings, a clock turret, and a short steeple were added in 1734, probably to give the church verticality, and now serve as a porch. The conical steeple with a cross above the octagonal drum of the clock turret is a characteristic feature of Armenian churches globally, including the Cathedral of Holy Etchmiadzin in Armenia (17th century), the Akdamar Cathedral in Lake Van in Turkey (10th century), and, closer to Calcutta, the Armenian Church of the Holy Resurrection in Dhaka (18th century). With its distinct Armenian features, this is an example of global interconnectedness of diaspora communities through architecture.

\section{Jews}

Jewish immigration to Calcutta started in the late 18th century via Surat, as Surat's prosperity as a trading port declined and that of Calcutta grew. The mid-19th-century religious persecutions in Baghdad (Mukherjee 2009: 86) brought another wave from Baghdad, Aleppo, and Basra, and the community became known as the "Baghdadi Jews". From their arrival in Calcutta they established "large commercial houses" dealing in tobacco, jute, and real estate (Ray 1996: 570) and settled in Kalutola, Burrabazar and Bowbazar (Omalley 1911). Large religious structures soon emerged in the Jewish quarter, such as the Neveh Shalom Synagogue (1831, rebuilt in 1911), the Beth El Synagogue (1856), and the Magen David Synagogue (1884).

The synagogues in Burrabazar follow the typical floor plan of a Jewish synagogue, having a large rectangular prayer hall with a wide nave and two aisles. The three-level nave is separated from the two-level aisles by rows of columns. Located centrally in the nave is the Bimah, a dais on which the Rabbi conducts services. At the apsidal end of the nave is the Hekkal, the sanctuary, covered by a hemispherical dome, where the Torah scrolls are kept and with a plaque of the Ten Commandments. The vaulting above the Hekkal represents the heavens, with stars painted on a blue background. The side aisles have benches for men and women and children are seated in a gallery. The nave and aisles have flat roofs supported by large cast-iron beams and wooden joists. As well as Judaic iconography, Colonial elements, popular in construction at the time, are also present in the interiors.

In the Beth El Synagogue, cast-iron columns with unusual capitals support an entablature with a decorative frieze and cornice. Cast-iron brackets support the overhanging galleries. The synagogue has a large stained-glass window with lancet arches over its entrance, letting light flood in, and a traditional façade adorned with Jewish symbols. On the twin pilasters dividing the three bays of the front façade are scroll-like designs framing a Star of David. The central bay features a Menorah, a seven-branched candelabrum, flanked by two Stars of David. Above this is a decorative pediment also serving as a clock tower. At both levels of the two side bays there are tall bifora windows of unusual proportions.

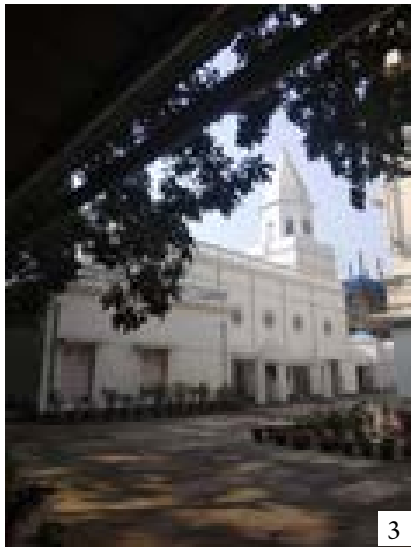

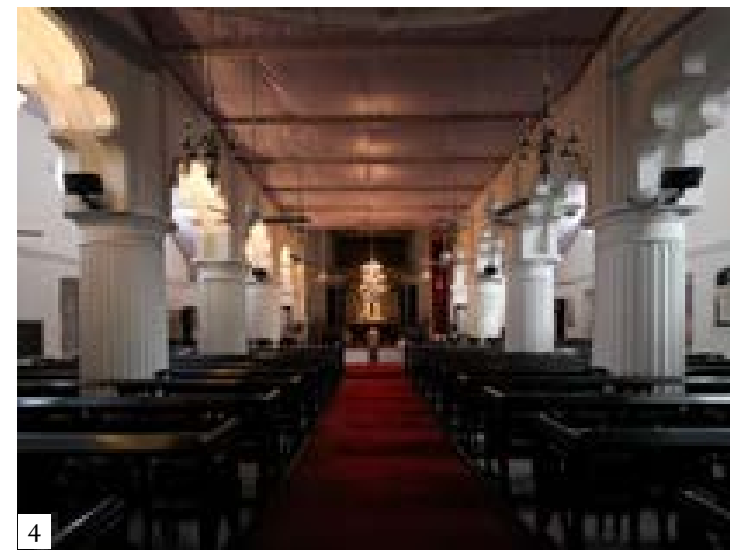

Figure 3: The Armenian Church of the Holy Nazareth in Burrabazar

Figure 4: Stout columns with unusual arches at the Armenian Church of the Holy Nazareth in Burrabazar (Kolkata Trips, https://kolkatatrips.com/ armenian-church/) 
Figure 5: Plan of the Beth El Synagogue

Figure 6: Interior of the Beth El Synagogue

Figure 7: Stained glass over the women's gallery at the Beth El Synagogue

Figure 8: External façade of the Beth El Synagogue

Figure 9: Interior of the Magen David Synagogue

Figure 10: The Hekkal of the Magen David Synagogue

Figure 11: External façade of the Magen David Synagogue
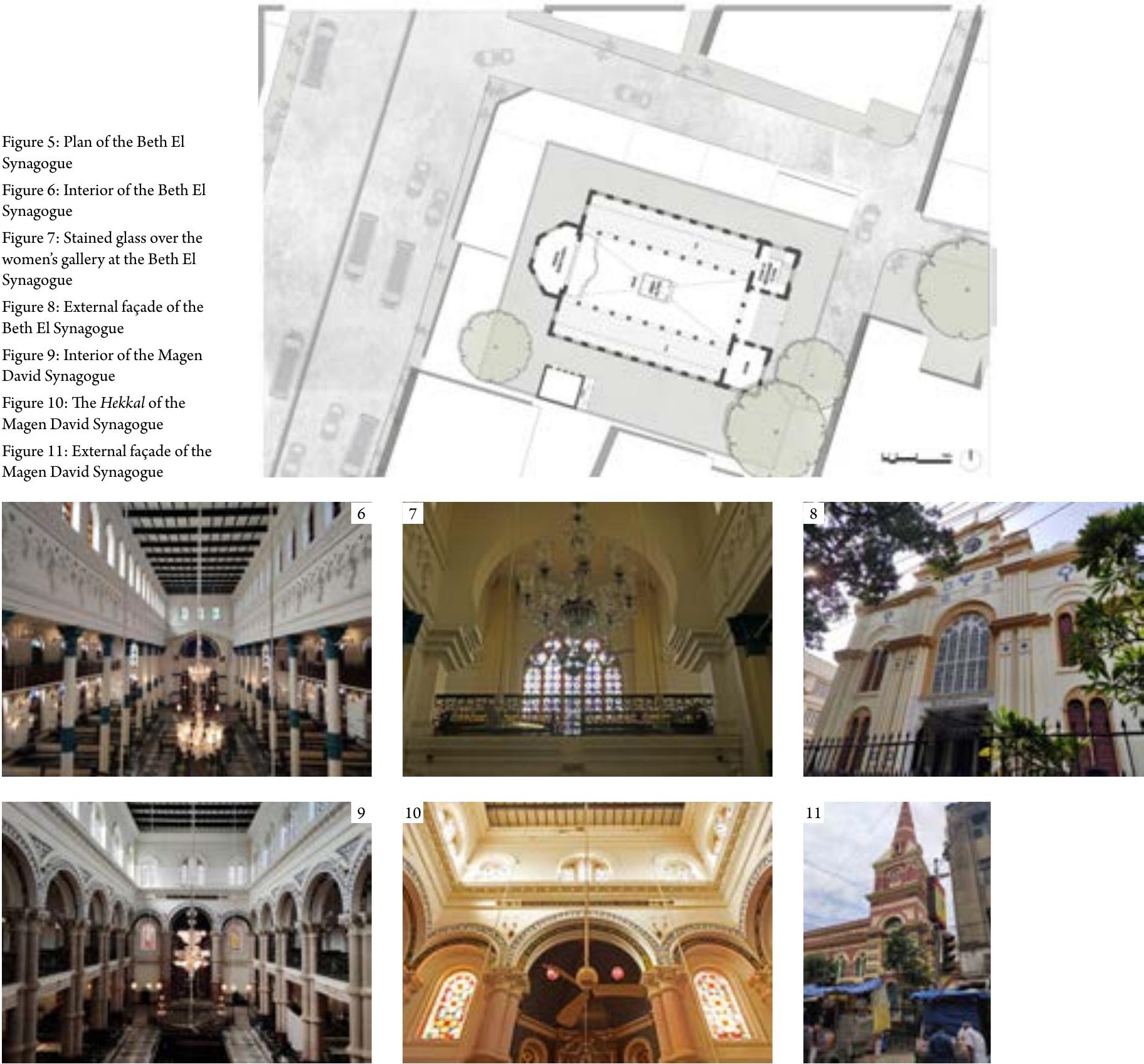

The Magen David Synagogue, built when Jewish trade in Calcutta was at its height, is much grander. Its stone columns have Corinthian capitals supporting semicircular arches. The delicate incised plasterwork on the arches, with floral patterns and Hebrew excerpts from the Psalms on the archivolts, forms a striking textural contrast with the stone. A stained-glass rose window and fanlights let in a diffuse light. Many of the materials used to build this synagogue were imported from Europe (Silliman 2018). Its façade blends European-style Classicism with a traditional spatial layout, indicating a shift from a traditionally Judeo-Arabic style to a Judeo-European one. Inspired by the multiple churches in the vicinity, it adopts the popular feature of a steeple. It is designed in Renaissance Revival style, as shown by the series of mullioned Roman windows on the façade, the moldings on the arches, the dentiled cornices, and the chamfered, rusticated quoins.

These synagogues generally show a fine blend of the traditional architecture of a diaspora community with the Colonial architecture of the time.

\section{$\underline{\text { Parsis }}$}

The Parsis migrated to India, largely to the west coasts of Bombay and Gujarat, between the 8th and 10th centuries with the persecution of Zoroastrians in Persia. In the late 18th century the Parsi community arrived at Calcutta from 
Figure 12: View of the external façade of the Banaji Agiary, showing the Tuscan columns and the wooden louvered screens

Figure 13: The front porch of the Banaji Agiary with rectangular pilasters and alternating triangular and segmental pediments above the openings

Figure 14: Plan and section of the Banaji Agiary, at Ezra Street

Figure 15: Front façade of the Anjuman Atash Adaran

Figure 16: External façade of the Anjuman Atash Adaran showing the Neo-Classical influences

Figure 17: Zoroastrian iconography of the Faravahar on the (a) stained-glass paintings and (b) frosted glass etchings, at the Anjuman Atash Adaran Figure 18: Zoroastrian iconography of the Atash (Holy Fire) on the tympanum of the arch
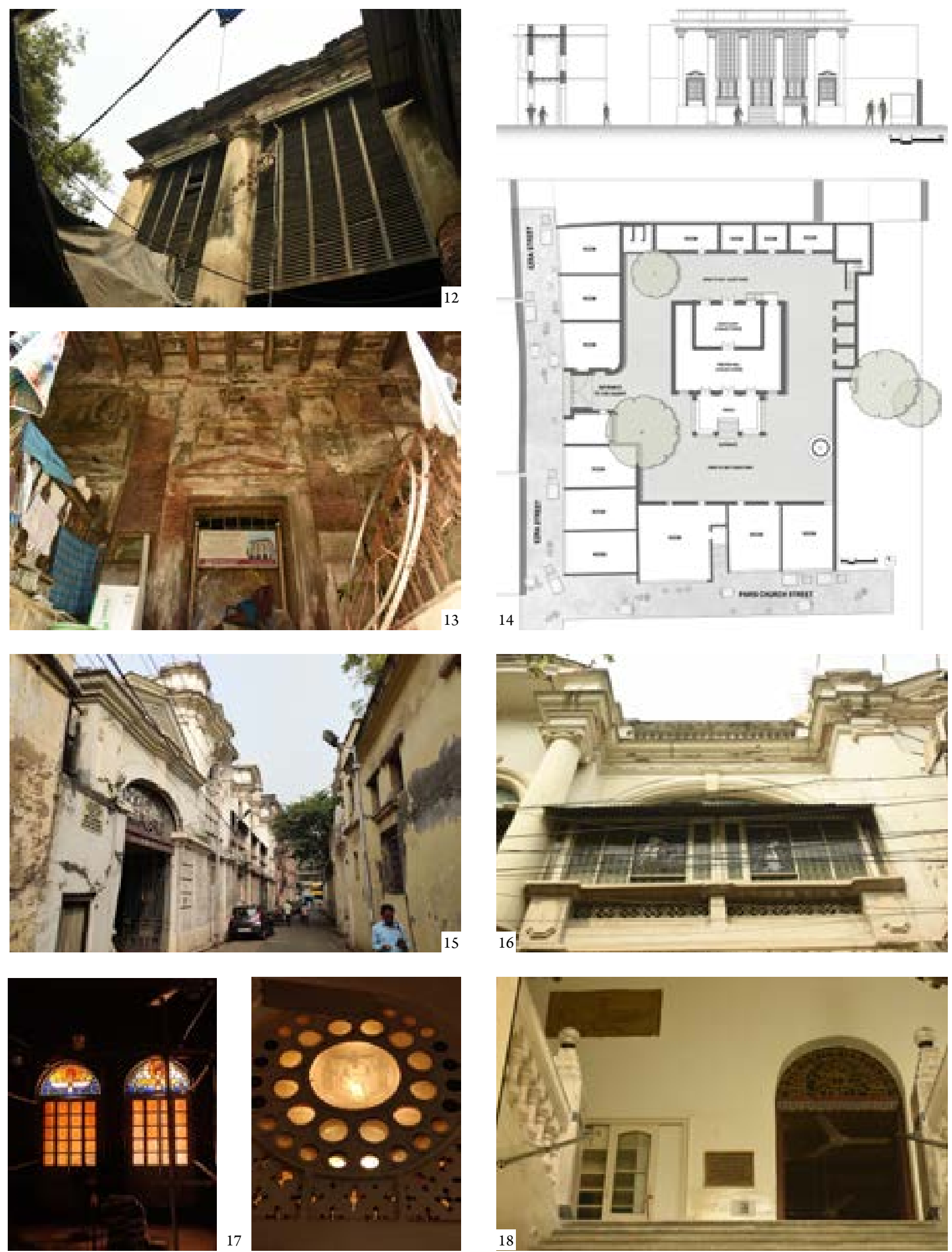
Surat and soon took over the shipping industry and made significant philanthropic contributions to the city (Madan 1990: 62).

Calcutta has two Parsi fire temples: the Rustomji Cawasji Banaji Agiary (1839) and the Anjuman Atash Adaran (1912). Their spatial layout is fairly simple, typical of fire temples in western India and even the Middle East.

The Banaji Agiary, built on a high plinth, is entered via a flight of steps and a porch leading into a rectangular temple with an antechamber and a sanctum, the Atashgah containing the Atash or Holy Flame. The sanctum has an opening in the roof to let out smoke. Borrowing from European forms, the Banaji Agiary is designed in the Classical style. Four Tuscan columns supporting an entablature adorn the front façade symmetrically. The ornamentation on the entablature is unidentifiable due to its ruinous condition. Large wooden louvered screens, a shading device suited to these climes, and decorative cast-iron grilles with floral patterns surround the porch. Another borrowed Renaissance feature is the alternating triangular and segmental pediments capping the five openings of the façade. Unlike other fire temples in the country, especially in west India, the façades of the Banaji Agiary are not heavily embellished with Zoroastrian iconography.

By contrast with the Banaji Agiary, the Anjuman Atash Adaran is much adorned with Colonial as well as Zoroastrian features, although its plan is similar. The street-side façade is divided into five bays, with the central and end ones projecting slightly. The groundfloor façade is plain with vermiculations. On the upper floor, the central bay has two columns with Ionic capitals supporting a semicircular pediment, while the end bays have pilasters with a triangular pediment above. The end bays also have rose windows while the three middle ones have large semicircular arched openings with projecting keystones. All the openings contain stained glass with Zoroastrian iconography. Deep heavily molded cornices run along the façade at terrace and parapet levels. In the interior, Zoroastrian icons in the form of the Lamassu (an Assyrian protective deity with human head and the body of a winged bull or lion), the Faravahar (a winged sun disk with a male figure in the center), and the Holy Fire are repeatedly expressed in stained-glass paintings, etchings on frosted glass, wall panels, and cast-iron grilles in the arch tympanums.

\section{$\underline{\text { Anglo-Indians }}$}

By the late 1700s, a new community with a complex social structure had been formed - the Eurasians. Amongst these, the Anglo-Indians settled in the densely commercial and cosmopolitan environs of Bowbazar. The wealthier part of this community eventually moved to the newer southern districts, closer to the European quarters, but the less affluent part remained in this neighborhood. Bow Barracks was designed as a garrison's mess for the army during World War I, but it was eventually leased to the Anglo-Indian community by the Calcutta Improvement Trust. As in most barracks, the architecture is minimalistic, functional, and symmetrical; somber without ornamentation. The precinct comprises 132 apartments of three types arranged in seven rectangular structures, each three stories high. Their façades have minimal decoration, with plain rectangular cornices and segmental arches devoid of trim or moldings. Their aesthetic quality derives from functional elements such as the louvered screens on the verandahs, letting in the breeze but keeping out the harsh sun, or their materials: exposed

Figure 19: Plan of Bow Barracks showing the ground floor plans of the seven blocks

Figure 20: View of the Barracks showing the exposed red brick façade with minimal ornamentation, segmental arched openings with louvered window shutters and narrow verandah with wooden louvered screens
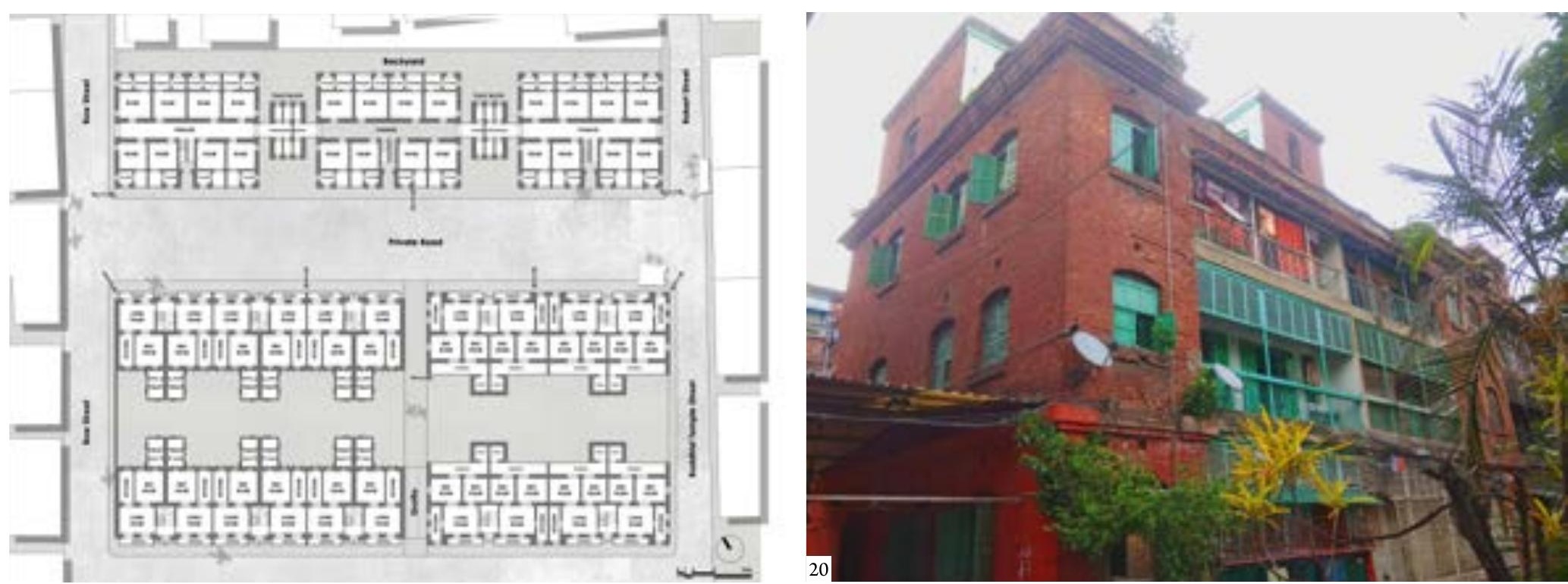


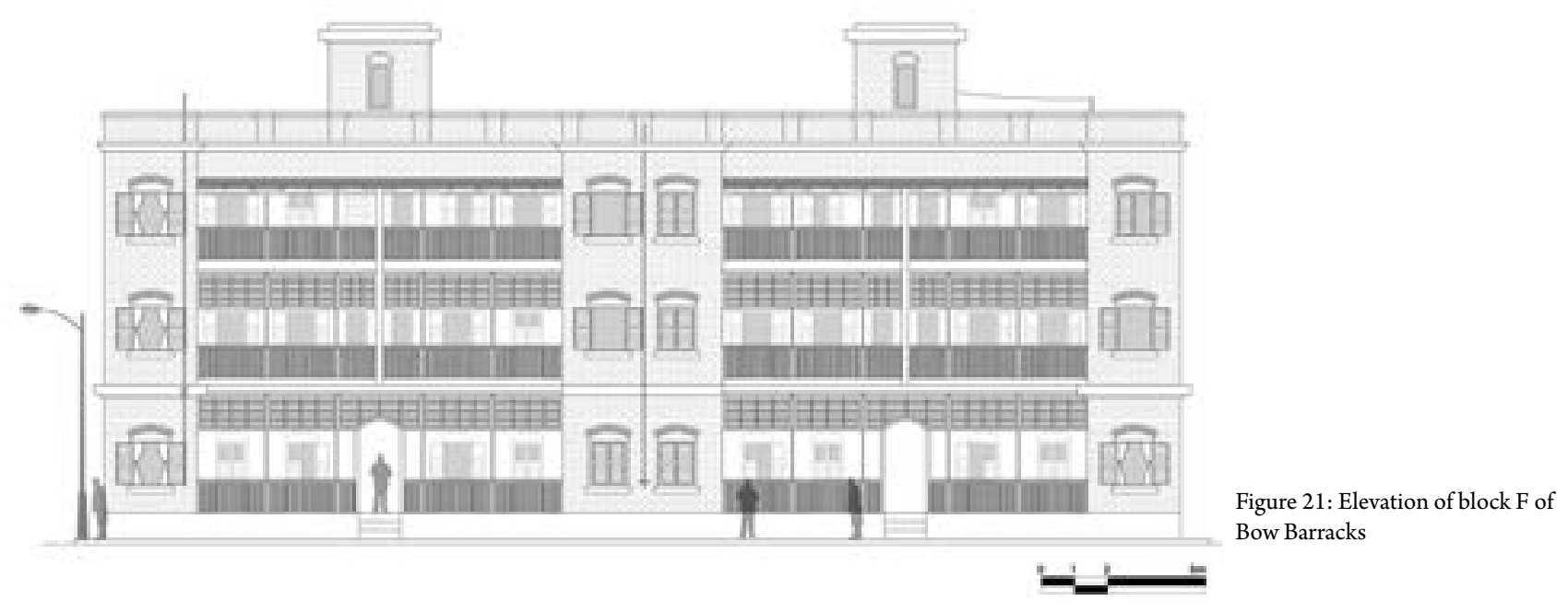

brick and cast-iron structural supports, cheap and widely available at the time of building. The wide private street between the blocks is used for gatherings during festivals like Christmas and Easter and also in everyday life.

\section{Chinese}

The Chinese began to settle in Calcutta much later than other nationalities. In 1780 Yong Atchew was the first Chinese to set up a plantation, 15 miles south of the city. The Calcutta Chinese were noticed in the early 1800 s and from then there was an influx from various parts of China, settling around Bentinck Street, Phears Lane, Tiretta Bazaar, and stretches of Chitpur Road, forming a distinctive Chinatown with "traditional Chinese temples, dragon-architecture, gaily-painted signboards and festoons in their bold and picturesque language with the rustle of red silks and the aroma of Chinese food so temptingly around" (Sircar 1990: 64).

Unlike the places of worship of Armenians, Jews or Parsis, which are grand in scale, the Chinese temples are much humbler. This may be due to the different types of trade that these communities engaged in. While the Armenians, Parsis, and Jews were involved in larger businesses, such as

Figure 22: View of the Nam Soon Temple from its front yard

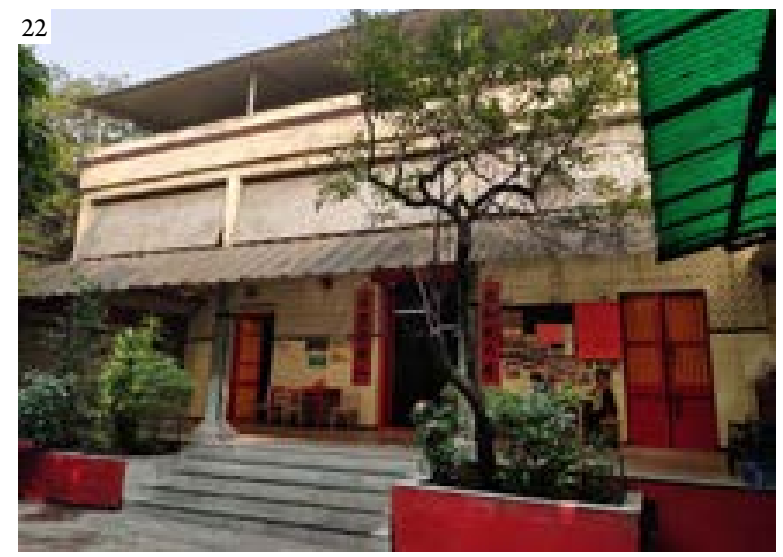

shipping, coal mining or real estate, the Chinese engaged mainly in carpentry, shoe-making, and opium-dealing. As the Chinese migrated to Calcutta, to the Tiretta Bazaar trading area, migrant groups from particular villages would each set up their own temple, which also became their meeting places. This gave rise to six diverse temples, each belonging to a particular clan, with their own various deities and no typical layout being followed. Like all Chinese diaspora settlements, Calcutta's Chinatown incorporated many local features and also adopted Colonial elements. The temples are on a human scale, no more than two stories high and often rectangular in plan, with a courtyard and an open front or verandah. The temple façades have a distinctive rectangular entrance with Chinese calligraphy on brightly colored plaques and hanging Chinese lanterns, making these temples stand out despite their humble scale. The interiors are richly decorated, with an intricately carved wooden screen at the threshold of the shrine room and a structure hanging from the roof with imagery of flowers, fruits, birds, and mythical figures. In most temples, Chinese war weapons are displayed. The interiors are in bright vermillion, yellow, and green, the auspicious colors of traditional Chinese architecture.

Figure 23: Intricate woodwork in the Nam Soon Temple

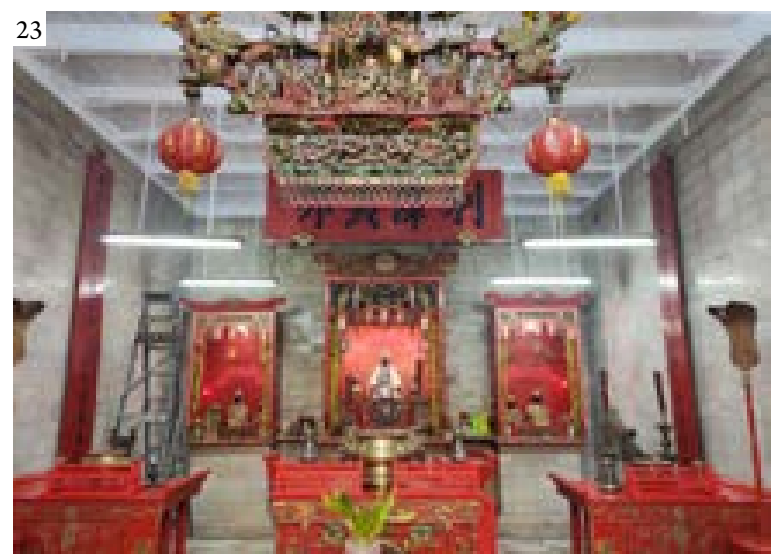



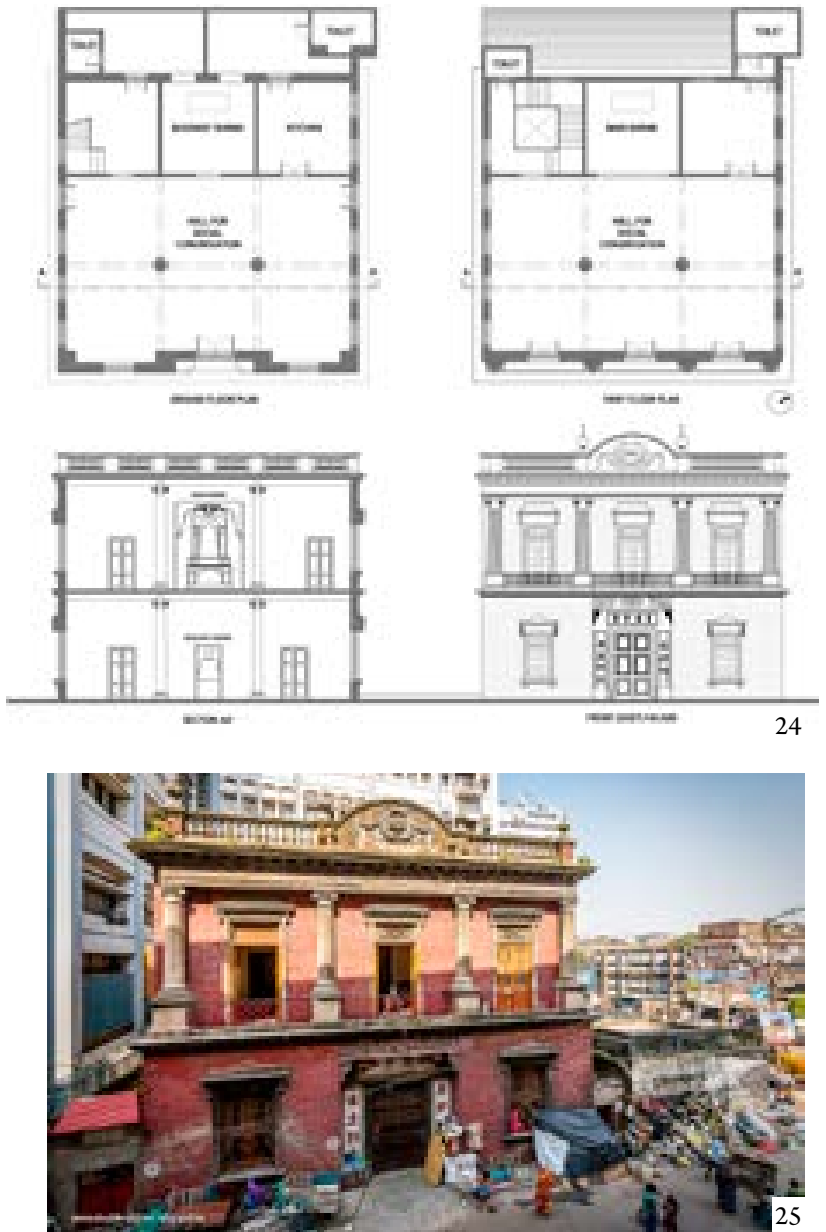

Figure 24: a) Ground floor plan b) First floor plan c) Section AA' d) Front façade of the Toong On Temple (Base drawings by The Cha Project, https://issuu.com/buzzzmedia/docs/thechaprojectreport_red) Figure 25: Neo-Classical facade of the Toong On Temple at Tiretta Bazaar

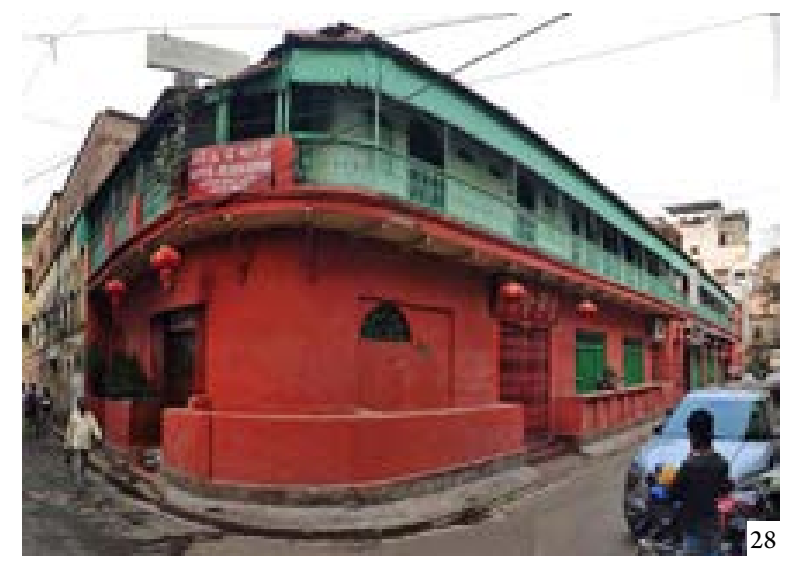

The Nam Soon temple is the oldest one, and has a charming simplicity. It is a single-story structure with a front yard leading to a verandah, supported by slender rectangular pillars and clad with glazed ceramic tiles. The verandah leads to three rooms, with an altar in the central one. The Sei Vui temple is a long narrow structure with its altar on the ground floor. The main doorways have brightly colored plaques with Chinese calligraphy on three sides. The upper
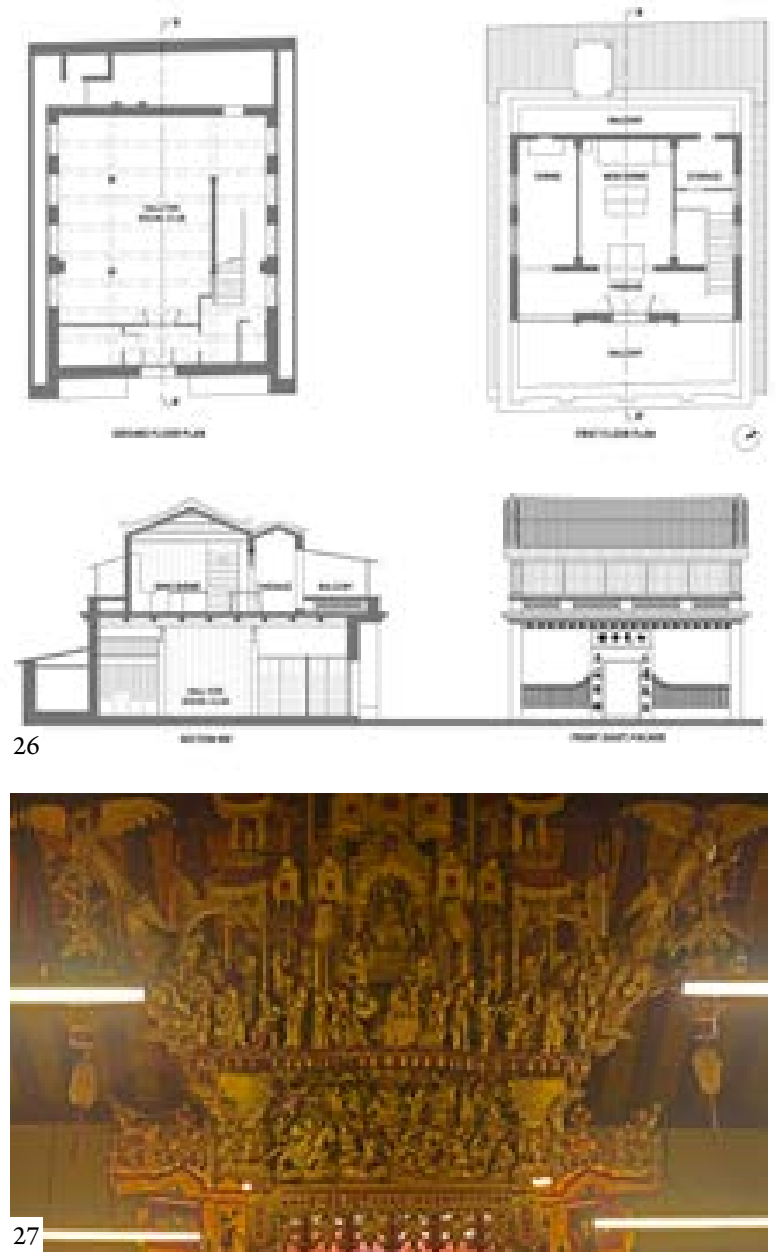

Figure 26: a) Ground floor plan b) First floor plan c) Section BB' d) Front façade of the Sea Ip Temple (Base drawings by The Cha Project, https://issuu.com/buzzzmedia/docs/thechaprojectreport_red)

Figure 27: Intricate woodwork in front of the altar at the Sea Ip Temple

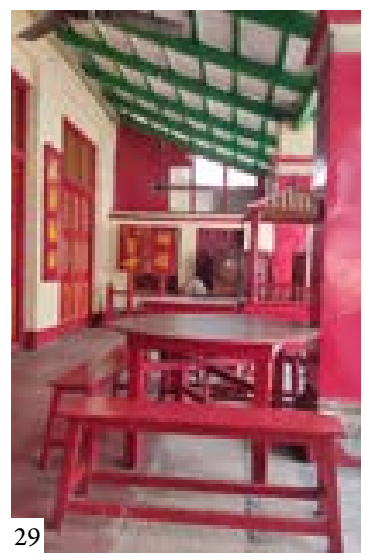

Figure 28: View of the Sei Vui Temple showing the brightly painted ground floor and the long and narrow veranda on the upper floor, with cast iron railings and timber screens

Figure 29: Brightly painted interiors of the Chooney Thong Thien, plaques with Chinese calligraphy, and column capitals with the Meander pattern common in Chinese ornamentation

floor is a continuous verandah with cast-iron railings and a timber screen running the length of the facade to keep out the fierce local sun. The Chooney Thong Thien and Gee Hing temples are two-story structures with the altar on an upper floor, opening onto a long verandah overlooking the street. Chooney Thong Thien has many interesting features, including column capitals with the meander or Greek key ${ }^{1}$ pattern, widely used in traditional Chinese 
architecture, and decorative wooden guardrails on the door and shutters. The Sea Ip Temple is a two-story structure, rectangular in plan, with a community hall on the lower floor and the altar upstairs. With its curlicue sloping roof, clay tiles, and upturned corners, the temple draws strongly on Chinese tradition. The Toong On Temple is rectangular in plan, with a community hall on the ground floor and an altar upstairs. The façade of this later temple borrows from the Classical style, with elements such as fluted columns with Ionic capitals, ornamental cornices above windows, dentiled cornices, semicircular pediments with stucco, festoons, and a parapet with decorative balusters.
The above discussion of some of the built heritage of the migrant communities of Central Calcutta shows that the architectural characteristics of these structures are not necessarily alien to the communities of today. The structures are a unique mix of the styles of traditional communities amalgamated with prevalent Colonial features and elements native to the city, expressed through differences in layout, scale and proportion, street interfaces, materials, construction techniques, ornamentation, and iconography. The main heritage resources of the communities located in the neighborhoods of Burrabazar, Tiretta Bazaar and Bowbazar are listed in Figure 30.

\begin{tabular}{|c|c|c|c|c|c|}
\hline \multicolumn{6}{|c|}{ IOENTIFED SHARED HERTIAGE RESOURCES OF THE DWNOLUNG MNORITY COMMUNITIES OF CENTRAL CALCUTTA } \\
\hline st. No. & Past Namel Present Name & $\begin{array}{c}\text { Year of } \\
\text { constructi } \\
\text { on }\end{array}$ & $\begin{array}{l}\text { Associated } \\
\text { Community }\end{array}$ & Protection Status & $\begin{array}{l}\text { Use / Functional } \\
\text { Typology }\end{array}$ \\
\hline 1 & $\begin{array}{l}\text { Armenian Chureh of the Holy } \\
\text { Nazareth }\end{array}$ & $1663 / 1724$ & $\begin{array}{l}\text { Cabata Ammenian } \\
\text { comnurity }\end{array}$ & $\begin{array}{l}\text { Protucted by Kolkata } \\
\text { Municipal Conporation } \\
\text { (KNC) - Grase I }\end{array}$ & Religous \\
\hline 2 & Nam Ssen Temple & 1820 & $\begin{array}{l}\text { Calatis Chirese } \\
\text { comnuriay }\end{array}$ & Protectad by KMC - Grase I & $\begin{array}{l}\text { Religious \& Educational } \\
\text { (Primay and Modte } \\
\text { School) }\end{array}$ \\
\hline 3 & $\begin{array}{c}\text { Rustomjee Camasjee Banaji } \\
\text { Agiary }\end{array}$ & 1839 & $\begin{array}{l}\text { Calouta Parsi } \\
\text { conmunity }\end{array}$ & Protochad by KMC - Grade I & Roligoss \\
\hline 4 & Bete El Synagogue & 1856 & $\begin{array}{l}\text { Calouta Jowish } \\
\text { Cortmunty }\end{array}$ & $\begin{array}{c}\text { Prolected by Auchaeological } \\
\text { Survey of Inda (Kolkata } \\
\text { Crolle) }\end{array}$ & Religious \\
\hline 5 & $\begin{array}{c}\text { Chesney Thong Thien Have } \\
\text { Temple }\end{array}$ & 1859 & $\begin{array}{l}\text { Calouta Chinese } \\
\text { community }\end{array}$ & Protected by KMC - Craso I & Religious \\
\hline 6 & Magen Darid Synagogue & 1884 & $\begin{array}{l}\text { Calcutta Jewish } \\
\text { Cormmunty }\end{array}$ & $\begin{array}{c}\text { Prolected by Avchaeological } \\
\text { Survity of india (Kolota } \\
\text { Crole) }\end{array}$ & Religous \\
\hline 7 & $\begin{array}{l}\text { Elias Meyer Sebool and } \\
\text { Talmund Torah }\end{array}$ & $\begin{array}{l}\text { Mid 19h } \\
\text { Cortuy }\end{array}$ & $\begin{array}{l}\text { Calouts Jowish } \\
\text { Communty }\end{array}$ & Urerotectod & Edicational bestade \\
\hline 8 & Sea ip Temple & 1906 & $\begin{array}{l}\text { Calatis Chirese } \\
\text { comnunily }\end{array}$ & Frotectod by KMC - Crado I & Revigos \\
\hline 9 & $\begin{array}{l}\text { Sei Vui Temple and Voiling } \\
\text { Club }\end{array}$ & 1908 & $\begin{array}{l}\text { Calatla Chirese } \\
\text { eomnurity }\end{array}$ & Protectad by KOMC - Grade I & $\begin{array}{l}\text { Relojous and Community } \\
\text { gathering place }\end{array}$ \\
\hline 10 & $\begin{array}{c}\text { Manackjee Rustomjee } \\
\text { Oharamshala for Parsi } \\
\text { Travelers }\end{array}$ & 1909 & $\begin{array}{l}\text { Calauta Pars } \\
\text { community }\end{array}$ & Uncrolected & $\begin{array}{c}\text { Hospleality and } \\
\text { Communicy Gathering } \\
\text { place }\end{array}$ \\
\hline 11 & Neveh Shalome Synagogue & $\begin{array}{c}1911 \\
\text { (originaly } \\
\text { built in } \\
1831 \text { ) }\end{array}$ & $\begin{array}{l}\text { Calouta Jewish } \\
\text { Community }\end{array}$ & Protectad by KMIC - Grade I & Religious \\
\hline 12 & $\begin{array}{c}\text { Byramiee Mehta Zoroastrian } \\
\text { Alash Adran }\end{array}$ & 1912 & $\begin{array}{l}\text { Calouta Parsi } \\
\text { community }\end{array}$ & Protectad by KMMC - Grade I & $\begin{array}{l}\text { Religicus and Community } \\
\text { gathering place }\end{array}$ \\
\hline 13 & Toong On Temple & 1912 & $\begin{array}{l}\text { Calouta Chirese } \\
\text { comnurity }\end{array}$ & Protected by KUMC - Grade I & $\begin{array}{l}\text { Relogous and Commurity } \\
\text { gathering place }\end{array}$ \\
\hline 14 & Bow Barracks & 1912 & Ango hdan & Urerotected & Residertial \\
\hline 15 & Gee Hing Temple and Club & 1920 & $\begin{array}{l}\text { Calatha Cirese } \\
\text { commurity }\end{array}$ & Protectad by KUMC - Grade I & $\begin{array}{l}\text { Religous and Commurity } \\
\text { gathering place }\end{array}$ \\
\hline
\end{tabular}

Figure 30: Identified shared heritage resources of the dwindling minority communities of Central Calcutta 
Communities of today and their engagement with the shared heritage of Central Calcutta

After Indian independence the scenario began to change. The Anglo-Indians, largely dependent on the British for social security, started emigrating, unsure of their position in society in an independent India (Bhattacharya 2009: 143). With the creation of the state of Israel in 1948, many Jews emigrated there (Mukherjee 2009: 87). The SinoIndian war of 1962 led to large-scale emigration of Calcutta Chinese (Sircar 1990: 64). With the political changes, most of these communities lost their prosperity and migrated to the West in search of better opportunities. Their population began to dwindle and today only a few people of these minorities remain, struggling to protect their tangible and intangible cultural heritage in the city.

The neighborhoods of Burrabazar, Tiretta Bazaar and Bowbazar remain part of Calcutta's Central Business District, full of trading establishments. After the mass emigration of the original custodians of this heritage, the contemporary communities or "communities of today" inhabiting the area attach little or no value to it. To this day, the responsibility to protect these historic buildings rests with the remaining members of the ethnoreligious communities, who are largely unable to keep up with the task, given the departure of younger generations. In this scenario it is essential to seek participatory approaches for mobilizing contemporary communities to safeguard this heritage and prevent it from falling into dereliction. Two broad communities can be identified as stakeholders: the few remaining members of the ethnoreligious communities, and the occupational communities who work and live in these areas today. The next section of our paper seeks to apprehend their relationship with this shared heritage.

\section{Ethnoreligious communities}

This category includes not only the members of the ethnoreligious communities that continue to live or work here but also their worldwide diaspora.
The Armenian community of Calcutta, including a floating population of students, staff, and priests at the Armenian College and Philanthropic Academy, from various parts of the world, is actively involved in adequately maintaining its built heritage. This is funded by a trust headed by the Holy Church of Nazareth in Burrabazar.

The Jewish community of Calcutta takes pride in its shared built heritage and actively engages with it, though only a few Jews remain in the city. In the past decade its synagogues have been restored with funds from both the community itself and the diaspora. Seventy members of Jewish communities in Israel, the United States, Singapore, and Australia visited Calcutta for the reopening of the restored synagogues (Das 2008).

Calcutta still has a few hundred Parsis. While regular maintenance of the Byramjee Mehta Anjuman Atash Adaran is undertaken, the Banaji Agairy, the city's oldest agiary, has been encroached upon by a wholesale electrical market despite the temple having been declared a Grade I Heritage Building by the Kolkata Municipal Corporation, and community initiatives to protect it have been unsuccessful.

The Calcutta Chinese community is seeking to ensure the continuity of its intangible and tangible cultural heritage with aid from local and international organizations. For example, the Sei Vui Temple and Voiling Club, a Buddhist temple with an attached club and dormitory built in 1896 , was recently transformed into a Cantonese restaurant. The community decided to reuse the dormitory as a restaurant to ensure continued funding for the maintenance of the temple and club by future generations. The diaspora community also come here, especially during the Chinese New Year, to visit family and friends.

In the past decade the Anglo-Indian community of Bow Barracks has been struggling to protect the Barracks and get it listed by the Kolkata Municipal Corporation as a heritage site to prevent it from falling prey to land sharks. The

Figure 31: The Toong On Temple engulfed by the Telephone Bhavan

Figure 32: Street Elevation of Old China Town showing large office buildings surrounding the Toong On and the Sea Ip Temple
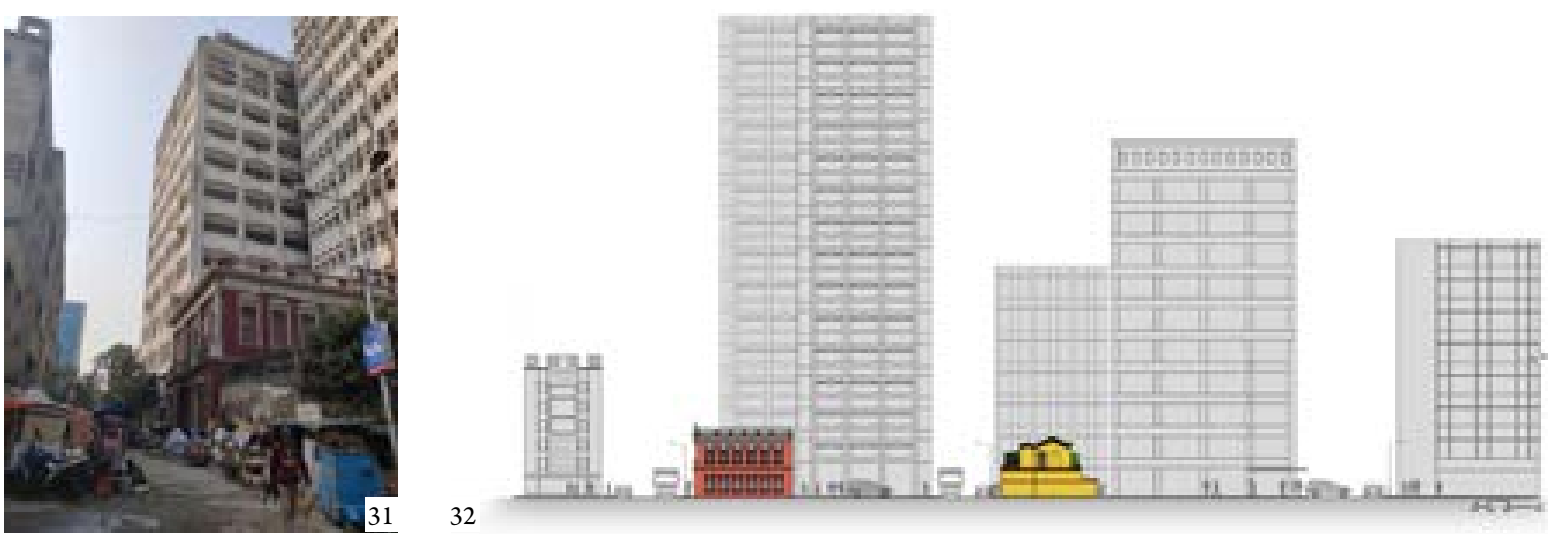
community also safeguards Anglo-Indian heritage through annual celebrations and frequent cultural gatherings.

\section{Occupational communities}

As well as the ethnoreligious communities, those that encounter this shared heritage on a daily basis are also important. This community attaches little value to these resources, but lives and works close to them. It includes the office-workers of Old Chinatown, shopkeepers and informal vendors along Brabourne Road outside the Armenian Church, Neveh Shalom Synagogue, and Magen David Synagogue, and wholesale electrical traders around the Rustomjee Cawasji Banaji Agiary.

The temples of Old Chinatown, in Tiretta Bazar, are in an area densely built up with public and private office buildings, overwhelming the temples and degrading the neighborhood. They not only disrupt the area's visual harmony and human scale but also overpower these heritage resources, with no regard for the historical, social, and architectural values that these structures offer. Disregard for built heritage can also be seen in the planning by local authorities, allowing the building of monstrous modern structures so close by the temples. This disconnect from heritage was glaringly reflected in the survey conducted with office-goers in Tiretta Bazaar, who were largely unaware of the area's historical and sociocultural significance. Most office-workers could not identify the six Chinese temples within $300 \mathrm{~m}$ of their workplaces. But once informed, the respondents agreed to Old Chinatown being a significant heritage resource. Some of the reasons accounting for this significance were: "different communities live here", "diversity gives Calcutta its identity", their importance as "an identity-maker”, "places of worship”, "historical value”, or as a "lineage of a section of society", and their relevance for "cultural fusion". However, some respondents said these structures had very little relevance to them personally, since they had no associational value for them, and the temples belonged to a community with whom they had little in common.

The shopkeepers and vendors on Brabourne Road have been engaged in business in this area for more than two generations now. While they were aware of the presence of the Armenian Church, the Neveh Shalom Synagogue, and the Magen David Synagogue, they were largely unaware of their historical and sociocultural significance. A majority recognized the structures as significant heritage resources of Calcutta, as "historical places", "tourist places" and "places of worship". Only a few, however, felt this heritage was relevant to them personally.

Similarly, the electrical wholesale traders at 26, Ezra Street, overpowering the Rustomjee Cawasjee Banaji Agiary, have been associated with this address for half a century. Yet even though most shopkeepers were aware of the building's historical and sociocultural value, they felt it was unnecessary to protect the Agiary, since it has "been closed for many years" and "does not have any worshippers", or because the "significance of the commercial activity on the premises far exceeded its heritage value", and they view these premises "only as a place for their business, with no personal association". They also felt that a restoration of the Banaji Agiary would have a negative impact on their businesses and that it was more important to retain the shopkeepers' livelihood than to conserve the temple. In both cases, the informal trade in the vicinity has left the buildings very much in the background, making them inconspicuous and undermining their heritage value due to the lack of any positively reinforced relationship with this built inheritance.
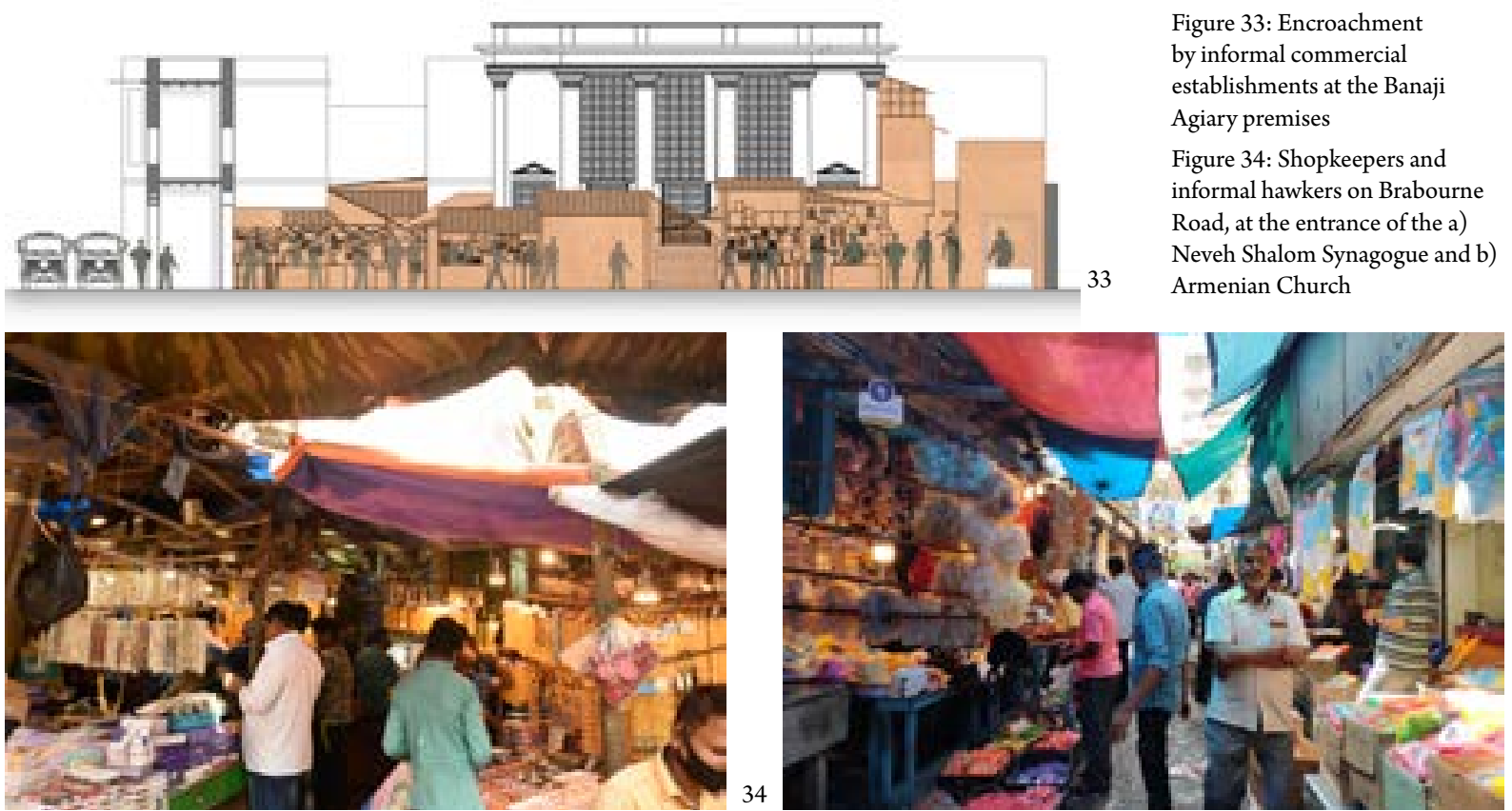


\section{Developing common goals}

Through our study some key questions emerged: how can Calcuttans of today be persuaded to protect heritage that they do not see as their own? How can this built heritage, whose original custodians are too few in number, be made relevant to a community that does not inherently identify with it? The neighborhood has great historical, associational, and sociocultural value as well as its distinct architectural character. It is a true representation of shared built heritage in Calcutta with far-reaching cross-cultural connections. The involvement of local contemporary communities in heritage preservation is essential, and so this section will look at possible methods for addressing the shortfalls in the engagement of these communities with heritage resources, increasing participation, and developing common goals for heritage protection.

The first step should be to generate awareness and recognition of the historicity of these neighborhoods which the communities of today identify as workplaces only. Heritage professionals, collaborating with members of the ethnoreligious communities, may help by organizing awareness-generating workshops at the heritage sites with traders, shopkeepers and office-workers in and around Burrabazar, Old Chinatown (Tiretta Bazaar) and Bowbazar, sensitizing them as to the area's historical and sociocultural significance, creating a first level of interaction between occupational and ethnoreligious communities. Heritage walks may be organized through historic neighborhoods, guided by heritage professionals and ethnoreligious figures, to build knowledge and inculcate a sense of pride in these business districts. Architectural heritage here may play a role in demonstrating the universal values of art, architecture, and beauty displayed through these structures that benefit not only the communities that built them but also those who now live and work in the vicinity. These structures transcend cultural boundaries and political divides by virtue of their artistic and architectural qualities, amalgamating the traditional architecture of diasporas with local and colonial attributes.

Engaging occupational communities with the intangible cultural heritage of ethnoreligious communities through craft workshops, food festivals, culinary workshops, etc., may result in increased associational value with this historic neighborhood. Collaboration with the city's educational institutes may be established so as to instill a discourse of cultural exchange at young ages. In this digital era, web-based engagement through digital tools may also be generated with help from the ethnoreligious communities. A compilation of the online archives of community members (photographs, letters, oral histories, narrations, memories, traditional recipes) may serve as a cultural repository. Such websites may be promoted to a wider audience through social media.
Central Calcutta's occupational communities must be helped to recognize the current state of these heritage resources and the need to safeguard them. Cognitive mapping exercises may be carried out with the communities to identify the threats and issues affecting the heritage and its vicinity. To ensure a balance between the needs of multiple communities and those of heritage resources, it is essential to facilitate dialogue between members of the ethnoreligious and occupational communities and also local government through public forums, focus groups or roundtable discussions. This will encourage mutual understanding between ethnoreligious and occupational groups, allowing them to meet on common ground, as well as directly expressing their concerns to political, civic, and professional representatives. Better coordination amongst the multiple communities will lead to better solutions and effective management of our cultural heritage resources.

\section{Conclusion}

The Armenian, Jewish, Parsi, Chinese and Anglo-Indian communities gave Central Calcutta a uniquely plural culture. The diverse architectural heritage generated as a result is a rich blend of the architecture of these traditions, mixed with European stylistic elements and local techniques and forms responsive to the city's climate.

As an indispensable part of Calcutta's history, this rich stock of built heritage is relevant not only to the stakeholder community that built it but also to the people of Calcutta today, as it testifies to the shared histories of multiple cultures in the city.

These structures should be seen not merely as houses of worship of bygone communities but also as exhibits of universal values of beauty in art and architecture which are relevant today and still able to serve all communities.

Our study showed that the needs and aspirations of the communities of today are not aligned with the conservation of built heritage. Various efforts should be made by heritage professionals to ensure that today's Calcuttans view these structures as valuable resources, understand the underlying values of sociocultural harmony that they represent, and have an increased sense of belonging and pride in these historic neighborhoods. A shift of attitude in the communities working here should be brought about, from identifying the areas of Burrabazar, Tiretta Bazaar and Bowbazar solely as workplaces to valuing the cultural amalgamation that this historic district represents.

These neighborhoods are reminiscent of Calcutta's cosmopolitan identity. With the diminishing population of migrant communities, their architectural heritage is vital to retaining this identity. We must ensure a sustained preservation of these shared built heritage resources 
of Central Calcutta, and this will occur only if the communities of today take ownership, safeguarding this irreplaceable heritage and becoming active participants in its conservation.

\footnotetext{
${ }^{1}$ The meander is a repetitive ornamental motif resembling a labyrinth or the meanders of a river, appearing in bronzes of the Shang Dynasty in China and later in Chinese architecture. This pattern, which also resembles a primitive key, was also extensively used in Greek and Roman architecture, from which the name "Greek key" derives. It is unclear whether the pattern may have had an ancient common source, but the motif was common in traditional art and architecture in both civilizations.
}

\section{References $\mid$ Referencias $\mid$ Referências}

Bhattacharya, Nandini. 2009. The Anglo-Indians of Calcutta: An Interview with Rudolph L. Rodriguez. In Bannerjee, Himadri; Gupta, Nilanjana; and Mukherjee, Sipra (eds.), Calcutta Mosaic, 142-150. New Delhi: Anthem Press.

Bhattacharya, Susmita. 2009. The Armenians of Calcutta. In Bannerjee, Himadri; Gupta, Nilanjana; and Mukherjee, Sipra (eds.), Calcutta Mosaic, 70-85. New Delhi: Anthem Press.

Bose, Nirmal Kumar. 1964. Calcutta 1964: A Social Survey. Calcutta: Lalwani Publishing House.

Edulji, Phiroze. 2015. Banajee Agiary in Calcutta is now an Electrical Market. News World India. https://parsikhabar.net/heritage/banajeeagiary-in-calcutta-is-now-an-electrical-market/11914/ (consulted on 05/11/2015).

ICOMOS. 2010. Changing World, Changing Views of Heritage: Heritage and Social change. Proceedings of the ICOMOS Scientific Symposium, 5-6. Dublin: ICOMOS International Secretariat.

Loth, Calder. 2016. The Complex Greek Meander. Institute of Classical Architecture \& Art. https://www.classicist.org/articles/classicalcomments-the-complex-greek-meander/\# edn1 (consulted on 02/09/2021).

Madan, C. J. 1990. The Parsis of Calcutta. In Chaudhuri, Sukanta (ed.), Calcutta The Living City, vol. 2, 62-63. New Delhi: Oxford University Press.

Mukherjee, Sipra. 2009. The Jews of Calcutta. In Bannerjee, Himadri; Gupta, Nilanjana; and Mukherjee, Sipra (eds.), Calcutta Mosaic, 86-95. New Delhi: Anthem Press.

Omalley, Lewis Sydney Steward. 1911. Census of India. Calcutta: Bengal Secretariat Book Depot.

Ray, Dalia. 1996. Jews in Indian History After Independence. Proceedings of the Indian History Congress, vol. 57, 568-574. http://www.jstor.org/ stable/44133361 (consulted on 20/10/2020).

Seth, Mesrovb Jacob. 1897. History of the Armenians in India: From the Earliest times to the Present Day. London: Luzac \& Co.

Sircar, Jawahar. 1990. The Chinese of Calcutta. In Chaudhuri, Sukanta (ed.), Calcutta: The Living City, vol. 2. New Delhi: Oxford University Press.

Solvyns, François Balthazard. 1811. Les Hindous, vol.3. Paris: Chezl' Antuer.

The cha project. 2014. A heritage-led revival of Kolkata Chinatown. https://issuu.com/buzzzmedia/docs/thechaprojectreport_red (consulted on 10/07/2020).

\section{Biography $\mid$ Biografía | Biografia}

\section{Sohini Pyne}

Sohini graduated from the Faculty of Architecture at Manipal University in 2017. She was initiated into the field of heritage conservation at Vikas Dilawari Architects, Mumbai, and was given the opportunity to work on a range of conservation projects under the guidance of leading conservation architect Vikas Dilawari. She has completed her post-graduate studies (M.Arch) in Architectural Conservation at the School of Planning \& Architecture, New Delhi, with a scholarship from the Ministry of Human Resource Development. Sohini hopes to advocate for increased community engagement with the urban heritage of Calcutta and for the integration of heritage conservation in urban planning policies in our historic cities. 